\title{
EASTERN MARGIN OF THE VAASA MIGMATITE COMPLEX, KAUHAVA, WESTERN FINLAND: PRELIMINARY PETROGRAPHY AND GEOCHEMISTRY OF THE DIATEXITES
}

\author{
HANNU MÄKITIE
}

MÄKITIE, HANNU 2001. Eastern margin of the Vaasa Migmatite Complex, Kauhava, western Finland: preliminary petrography and geochemistry of the diatexites. Bulletin of the Geological Society of Finland 73, Parts 1-2, 35-46.

Extensive biotite diatexites resembling S-type granitoids occur in the eastern part of the Vaasa Migmatite Complex (VMC, $1.89 \mathrm{Ga}, 6000 \mathrm{~km}^{2}$ ) at Kauhava, western Finland. These rocks have undergone a textural homogenization that has destroyed the primary bedding. Pre-migmatization structures are preserved only in inclusions. The diatexites are clearly peraluminous and have relatively high concentrations of $\mathrm{TiO}_{2}(0.7-0.9 \mathrm{wt} \%), \mathrm{CaO}(2.4-3.0 \mathrm{wt} \%)$ and total of $\mathrm{Fe}_{2} \mathrm{O}_{3}$ tot $+\mathrm{MgO}$ (6.6-8.8 wt $\%$ ). The contact of the diatexites against pelitic metatexites is usually a gradual zone, $1-200 \mathrm{~m}$ wide, but locally a boundary limiting places of higher melt fraction. The contacts indicate that the anatectic melt formed, with residual solids, has not ascended greatly; the VMC forms the most voluminous in situ melted rocks with granitoid appearance in Finland.

The study area also includes peraluminous orthopyroxene-bearing rocks, granitic in texture, which are hornblende free and have relatively high $\mathrm{TiO}_{2}(1.0-$ $1.2 \mathrm{wt} \%)$ and $\mathrm{MgO}(2.1-2.5 \mathrm{wt} \%)$ contents. They gradually change to biotite diatexites and also suggest fusion of metasedimentary rocks at reduced $\mathrm{a}_{\mathrm{H} 2 \mathrm{O}}$. The chemical composition of minerals in the orthopyroxene-biotite diatexite indicates crystallization conditions of high-grade metamorphism; $\mathrm{X}_{\mathrm{Mg}}$ in garnet is 0.23 , orthopyroxene has $3 \mathrm{wt} \% \mathrm{Al}_{2} \mathrm{O}_{3}$ and biotite contains over $5 \mathrm{wt} \% \mathrm{TiO}_{2}$.

Key words: migmatites, diatexite, metatexite, anatexis, chemical composition, Paleoproterozoic, Kauhava, Finland

Hannu Mäkitie: Geological Survey of Finland, P.O. Box 96, FIN-02151 Espoo, Finland.

E-mail:Hannu.Makitie@gsf.fi 


\section{INTRODUCTION}

Granitic melts formed in the crust by anatexis (partial melting) may segregate and ascend with fractionation to supply plutons or they may form (par)autochthonous diatexite bodies (e.g. Milord et al. 2001). Both rock types can petrographically be rather similar. Because granitoids and related rocks constitute a major proportion of the continental crust, their petrogenesis and how far they have ascended are important to know in order to understand crustal evolution. Geochemistry (in particular REE and isotopes) may clarify the petrogenesis of granitoids, but the petrography of contacts between diatexite bodies and metatexite migmatites gives (with geochemical signatures), in fact, best criteria on which to distinguish (par)autochthonous granitoids from intrusive granitoids (see Sawyer 1999).

The subject of crustal melt derived from metasedimentary rocks and, furthermore, supplying melt to plutons has uncertainties although experimental petrology has shown the general P-T conditions of the granite solidus and partial melting overlap (Wyllie 1983, White et al. 2001, and references therein). For example, the amount of melt formed is relatively small (up to some $30 \%$ ) in normal granulite facies conditions (4-8 kbar, 700$900{ }^{\circ} \mathrm{C}$ ), there are the questions of melt-residuum and melt migration, and fluid-present or fluid-ab-

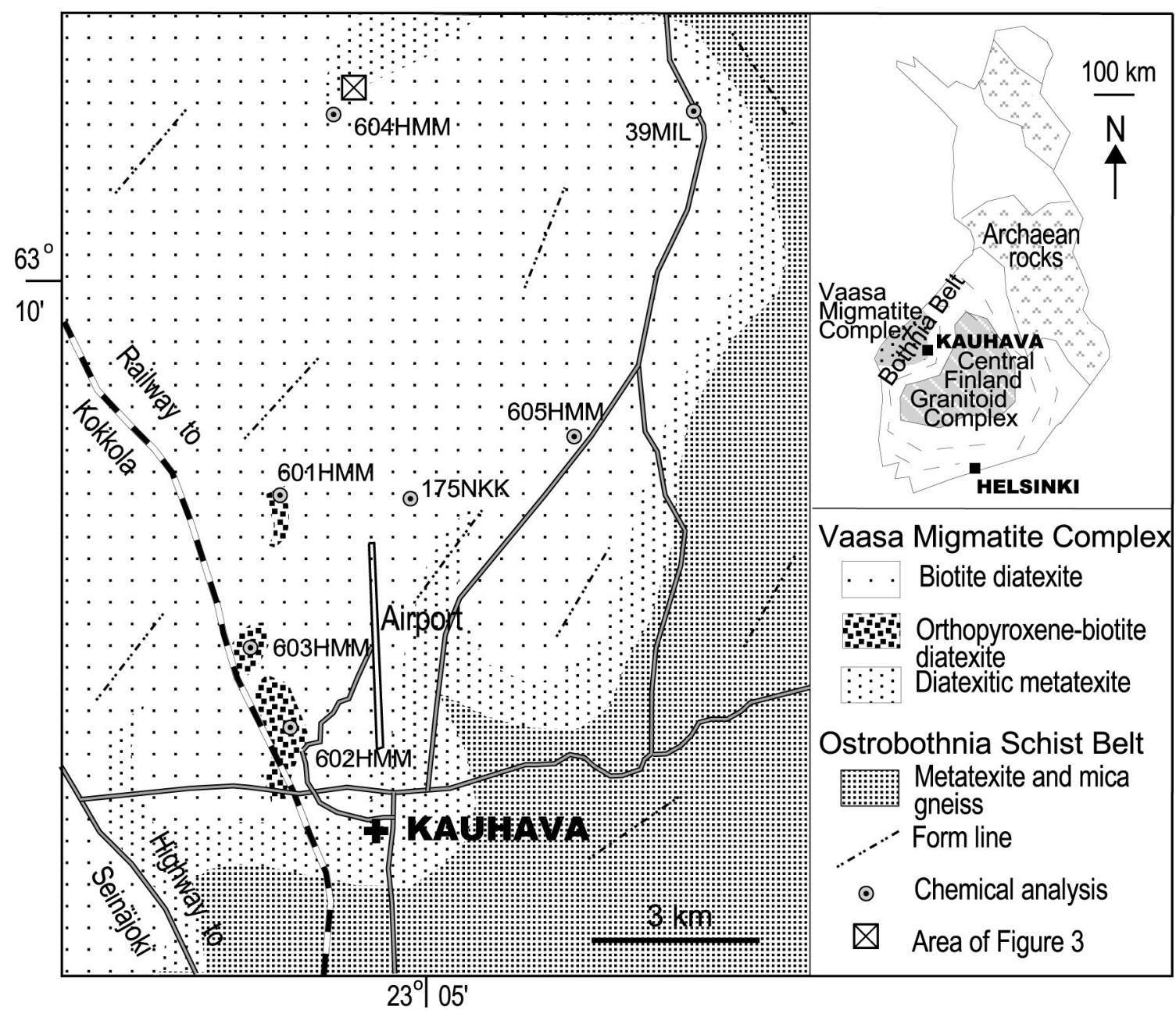

Fig. 1. Simplified geological map of the Kauhava area, western Finland. 
sent melting, as well as source of the fluids and locally increased heat budget (Clemens \& Droop 1998, Sawyer 1998).

The Vaasa Migmatite Complex (VMC, $1.89 \mathrm{Ga}$, $6000 \mathrm{~km}^{2}$ ), formerly called Vaasa granite (Fig. 1), is situated in western Finland and is predominantly composed of peraluminous rocks, often granitic in texture (Laitakari 1942, Mäkitie et al. 1999, Alviola et al. 2001). The genesis and nature of the VMC have been an unresolved problem for several decades, because it contains S-type rocks with granitoid appearance, supracrustal inclusions, heterogeneous populations of zircon, and, in particular, it does not show intrusive contacts with the surrounding high-grade metamorphic pelitic rocks (Alviola et al. 2001). For example, Saksela (1935) suggested that the VMC is a synkinematic granitoid, but Väyrynen's (1936) opinion was that the VMC belongs to a post-kinematic rock suite. Today, the VMC is usually shown on geological maps as a migmatite body, and its diatexite nature is generally accepted (Korsman et al. 1997, Koistinen et al. 2000). However, mapping remains to be carried out in large areas within the VMC.

This paper gives a preliminary description of extensive biotite-rich diatexites (locally orthopyroxene bearing) situated in the Kauhava area, in the eastern part of the VMC, with special emphasis on the contact between the diatexite and metatexite migmatites.

\section{GEOLOGICAL SETTING}

The Kauhava area belongs to the accretionary arc complex of central and western Finland, which is part of the Svecofennian Domain, 1.93-1.82 Ga old (Korsman et al. 1997). There are two major geological units in the area; (1) the western part occupied by relatively homogeneous VMC diatexites and (2) the eastern part dominated by porphyroblastic metapelites (containing greywacke and psammite interbeds) of the Ostrobothnia Schist Belt (Fig. 1) (Alviola et al. 2001). Both units belong to the Bothnia Belt of Finland (Nironen 1997). The VMC is largely surrounded by the Ostrobothnia Schist Belt, from which it is delim- ited by a lower aeromagnetic signature.

In the Ostrobothnia Schist Belt, regional metamorphic grade increases toward the VMC within the andalusite-sillimanite facies series (Alviola et al. 2001); the VMC is surrounded by metatexites. The highest-grade metamorphic rocks comprise migmatitic garnet-cordierite mica gneisses and rare orthopyroxene-bearing gneisses which occur at the border of the VMC. Indicators of extremely high-grade metamorphism such as sapphirinequartz and orthopyroxene-sillimanite are absent. The regional metamorphism was associated with the peak of the Svecofennian orogeny, 1.89-1.88 $\mathrm{Ga}$ ago, and scarce $\mathrm{U}-\mathrm{Pb}$ isotopic data indicate that the VMC is coeval with it (Vaasjoki 1996, Alviola et al. 2001).

Metavolcanic rocks and pegmatitic granites are common in the Ostrobothnia non-migmatitic turbiditic metagreywackes and muscovite-biotite schists situated some $25 \mathrm{~km}$ east of the Kauhava area (Vaarma \& Pipping 1998). The extensive Central Finland Granitoid Complex (CFGC) lies farther to the east (see Nironen et al. 2000).

\section{PETROGRAPHY}

\section{Terminology}

In the field, the classification and naming of rocks into diatexite, diatexitic metatexite and metatexite is open to subjectivity. In this paper, diatexite is a rock formed in situ by extensive anatexis and has rather granitic texture (Fig. 2a). These diatexites may contain a few supracrustal relicts, nebulitic features and schlieren but, probably, have a more granitoid outlook than the diatexites described, e.g. by Sawyer (1998), Milord et al. (2001) and Solar \& Brown (2001).

The metatexites are partially melted rocks where the pre-migmatization structures are generally preserved, so that bedding or earlier foliation can still be mapped. In diatexites these are lost. Near the VMC diatexites, the metatexites are transitional to (i.e. they grade to) diatexites and, therefore, are called diatexitic metatexites. 
a)

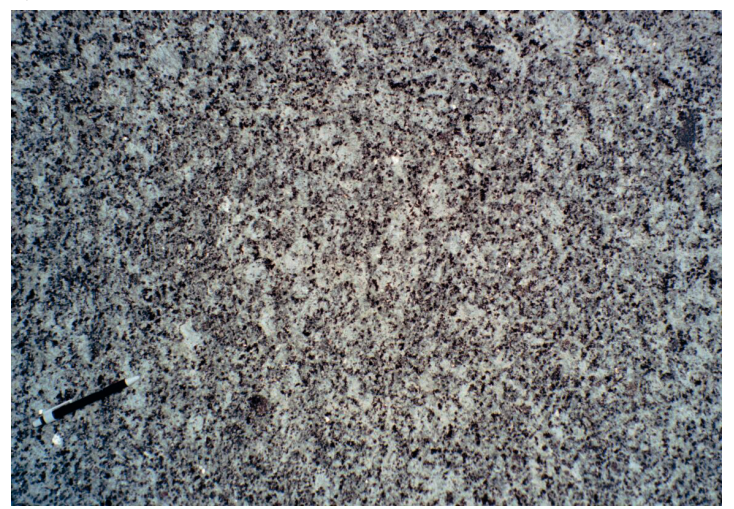

c)

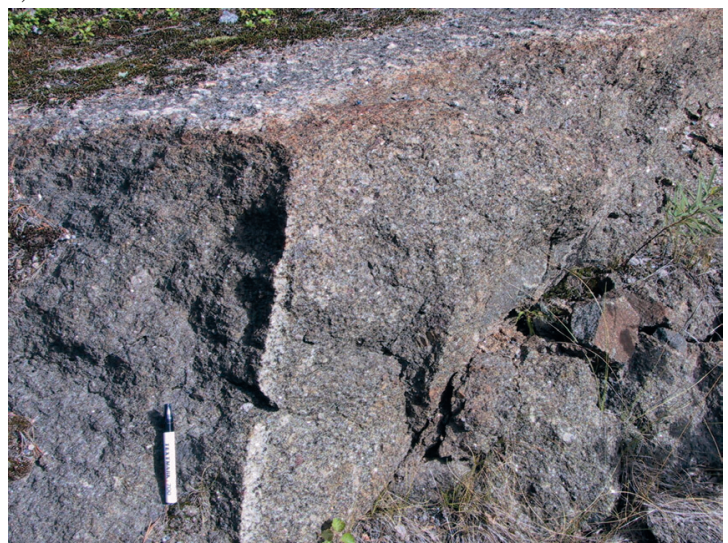

e)

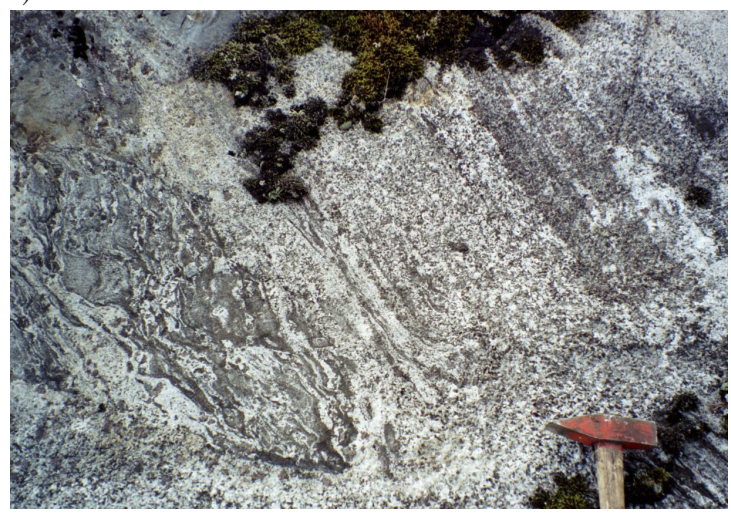

b)

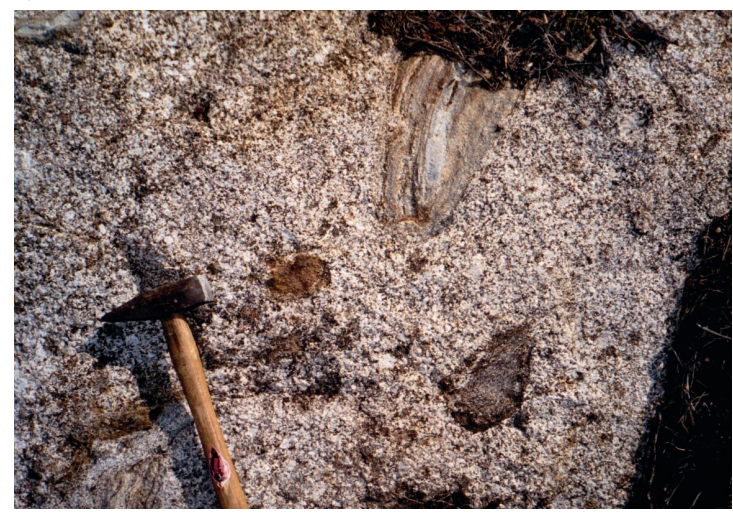

d)

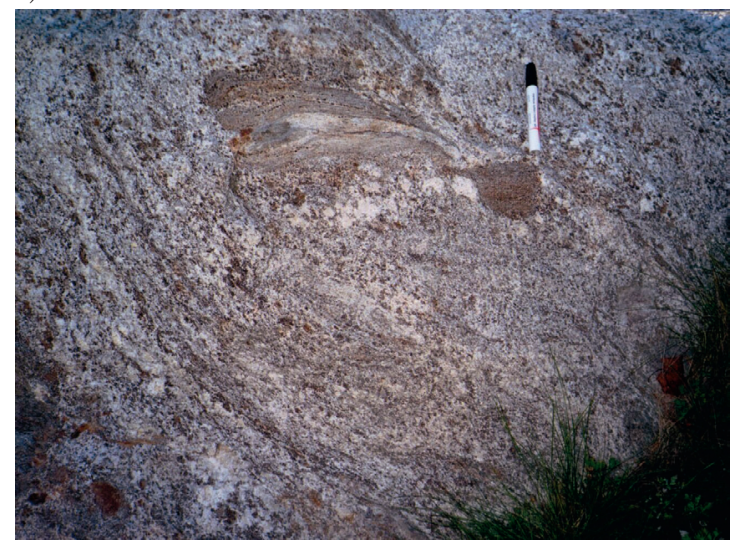

f)

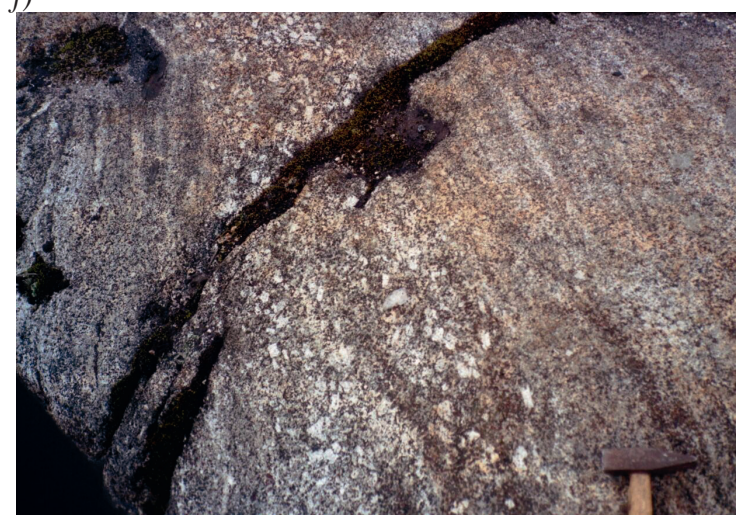

Fig. 2. Rocks of the Kauhava area. a) Surface of slightly porphyritic biotite diatexite, granitic in texture. $x=$ 7011670, $y=2451520$. b) Even-grained biotite diatexite containing supracrustal inclusions and biotite-garnet aggregates. $x=7003610, y=2455160$. c) Dark green, slightly porphyritic orthopyroxene-biotite diatexite. $x=$ 7005300, $y=2450740$. d) Diatexitic metatexite: transition from garnet-cordierite metatexite to diatexite. $x=$ 6998480, $y=2453290$. e) Relict of partially melted mica gneiss surrounded by diatexitic metatexite. The trend of mica gneiss is often parallel with that of the diatexitic metatexite. $x=7011710, y=2451570$. $f$ ) Nebulitic diatexitic metatexite, which contains practically autochthonous diatexite vein showing magmatic fabric. Note the rather sharp contact between the vein and metatexite. $x=7011700, y=2451580$. 


\section{Diatexites}

In the study area, the most common diatexites are biotite diatexites. The main mineral assemblage in them is; plagioclase (27-43 vol\%), quartz (30-39 vol\%) and biotite (16-27 vol\%). The K-feldspar content (locally as megacrysts) varies from 0 to $12 \mathrm{vol} \%$, and garnet is a common minor mineral. Other accessories include apatite, monazite, zircon, opaques and retrogressive muscovite and chlorite. The diatexites are greyish in colour.

Texturally, the biotite diatexites are weakly foliated (NE-SW trend, dip $80^{\circ}$ to SE), coarsegrained (1-8 $\mathrm{mm})$, relatively homogeneous rocks, which contain some indistinct schist inclusions, relicts of calcareous concretions, biotite-garnet aggregates $(\varnothing 1-4 \mathrm{~cm})$ and scarce schlieren (Figs. $2 \mathrm{a}, 2 \mathrm{~b})$. Granitic vein material is rare as are some clearly intersecting granite dykes. The biotite diatexites which do not contain inclusions resemble granitoids. Microscopic texture of the biotite diatexite is inequigranular and locally slightly deformed, e.g. biotite is strained. Quartz grains show undulatory extinction. Crystal faces are locally developed on plagioclase against quartz - a common texture found in diatexites (e.g. Mehnert 1968, Vernon \& Collins 1988). Some K-feldspar is altered to sericite and muscovite, and biotite (grain size varies largely) is decomposed to elongated quartz and plagioclase. Plagioclase has a coarser grain size than quartz.

Orthopyroxene-bearing biotite diatexites occur as small irregular bodies, $0.5-2 \mathrm{~km}$ in diameter, north of the town of Kauhava (Fig. 1). They are dark greenish, weakly foliated, granitic in texture and called orthopyroxene-biotite diatexites (Fig. 2c). They gradually grade to biotite diatexites, but at the contacts there may be transitional patchy diatexite varieties. Inclusions of supracrustal rocks are rare. The main minerals in the orthopyroxenebearing diatexites are plagioclase (39-57 vol\%), quartz (19-26 vol\%) and biotite (14-27 vol\%). Kfeldspar and orthopyroxene contents range from 1 to 7 vol\%. Garnet coexists with orthopyroxene as an accessory mineral. Other accessories are apatite, monazite, zircon and opaques.

The grain size of the orthopyroxene-biotite dia- texites is 1 to $6 \mathrm{~mm}$. In places, a few K-feldspar phenocrysts can have a diameter of up to $2 \mathrm{~cm}$. Microscopic texture in the orthopyroxene-biotite diatexites is more equigranular than in the biotite diatexites. Plagioclase has often crystal faces against interstitial quartz. K-feldspar is slightly cross-twinned, and biotite forms usually unstrained crystals, 1-2 mm in size. The magnetic susceptibility of the Kauhava orthopyroxene-biotite diatexites is $\sim 40 \mu \mathrm{Si}$, which is slightly higher than the magnetic susceptibility in the biotite diatexites.

\section{Mica gneisses and metatexites}

The mica gneisses situated immediately east of Kauhava are migmatitic and resemble those reported from the neighbouring areas (e.g. Alviola et al. 2001). The mineralogy of them is plagioclase, quartz, biotite, K-feldspar, garnet and cordierite. Garnet occurs in the neosome and palaeosome of the gneisses. Accessory minerals include e.g. hercynite and sillimanite. The gneisses are typically composed of metapelite and metagreywacke interbeds.

In the mica gneisses, the proportion of leucosomes increases westwards, towards the VMC, resulting in abundant metatexites. Near the VMC, the gneissic banding of the metatexites grades to a nebulitic banding due to intense melting; these rocks are called diatexitic metatexites (Fig. 2d). However, part of metatexite (or diatexitic metatexite) outcrop may still be gneissic while an other part is intensively migmatized. The mineral assemblages of the metatexites are similar to the mica gneisses, except that there are retrogressive andalusite and muscovite, and pseudomorphs after decomposed cordierite.

\section{Contact between biotite diatexites and diatex- itic metatexites}

The simplified geological map (Fig. 3) shows the boundary between the VMC biotite diatexite and the inclusion-rich diatexitic metatexite. Over a distance of 20 metres, the boundary consists of subparallel, irregular zones (width $0.05-1.0 \mathrm{~m}$ ) of nebulitic rocks transitional between diatexites and 


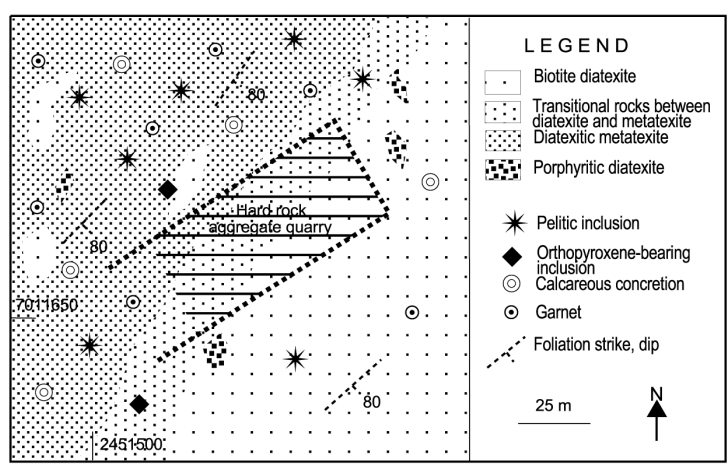

Fig. 3. Geological map of the boundary between the VMC biotite diatexites and diatexitic metatexites. Figures $2 a, 2 e, 2 f$, and 4 are from this well-exposed area, the location of which is shown in Figure 1.

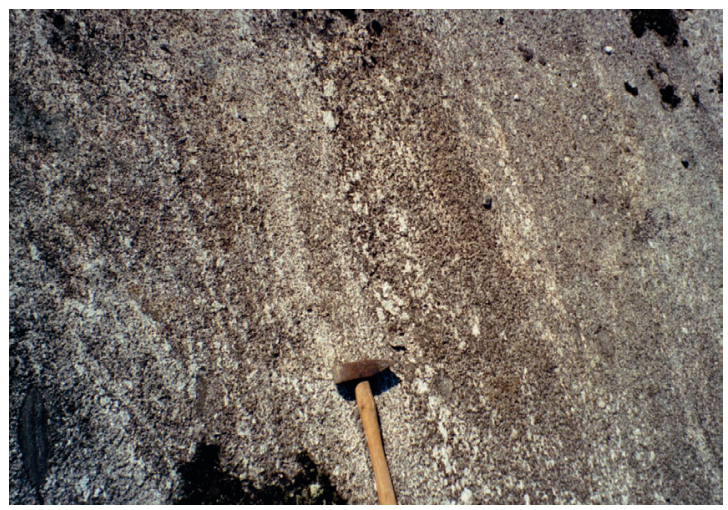

Fig. 4. Gradual contact zone (width $\sim 15 \mathrm{~m}$ ) between the VMC diatexite and diatexitic metatexite, composed of nebulitic rocks including supracrustal relicts and phenocrystic feldspar. $x=7011690, y=2451580$.

diatexitic metatexites (Fig. 4). The zones are not intensively foliated and the contact is not a fault. In fact they show features of deformation during melting. In the boundary zones, phenocrystic Kfeldspars occur in small elongated domains indicating the location suitable for the crystallization of K-feldspar.

In the boundary area, the proportion of inclusions is greater in the diatexitic metatexites than in the diatexites. The diatexitic metatexites may contain parts that are practically diatexites. The trend of partially melted mica gneiss is often parallel to the diatexitic metatexites (Fig. 2e).There are also some (par)autochthonous diatexite veins. Rather sharp contact between diatexite and diatex- itic metatexites is observed at the boundary of the diatexite vein (Fig. 2f). Here, the diatexite seems to intersect the diatexitic metatexite. However, instead of an intrusive boundary, the author suggests that here the melt fraction was higher because of melt migration. The contact does not show notable differences in the rigidity of the rocks.

Besides pelitic restites, the boundary area contains some large inclusions of dark green homogeneous rocks composed of plagioclase $(\sim 50$ vol\%), biotite ( $\sim 25 \mathrm{vol} \%)$, quartz ( $20 \mathrm{vol} \%)$, and orthopyroxene ( $\sim 5 \mathrm{vol} \%)$. Plagioclase is locally euhedral. Rarely, fine-grained retrograde amphibole surrounds orthopyroxene. The inclusions are inferred as restites although they resemble orthopyroxene-biotite diatexites, which are coarser in grain size.

\section{GEOCHEMISTRY}

\section{Analytical procedures}

To investigate the chemical characteristics of the Kauhava diatexites, four biotite diatexite samples and three orthopyroxene-biotite diatexite samples were analysed either by XRF or INAA in the Laboratories of the Geological Survey of Finland (GTK) and the Technical Research Centre of Finland (see Table 1). In addition, chemical compositions of the main minerals in the orthopyroxenebiotite diatexites were determined on thin sections using a Cameca Camebax SX50 electron microprobe at GTK. Locations of the samples analysed are shown in Figure 1.

\section{Whole rock chemistry}

The chemical composition of the biotite diatexites and orthopyroxene-biotite diatexites are relatively similar. However, the former have slightly higher $\mathrm{Rb}$ and $\mathrm{Y}$ contents and $\mathrm{A} / \mathrm{CNK}$, but lower $\mathrm{Ti}$, $\mathrm{Ca}$ and $\mathrm{V}$ contents and $\mathrm{K} / \mathrm{Rb}$ than the latter (Table 1, Figs. 5a, 5b). The $\mathrm{SiO}_{2}$ contents (63-68 $\mathrm{wt} \%$ ) in the diatexites overlap indicating that these chemical variations are not due to fractionation. 
Table 1. Chemical analyses of diatexites from the Kauhava area. The samples were analysed by XRF except 108NKK, which was analysed by INAA. Diatexites are coded as: 1 = biotite diatexite, 2 = orthopyroxene-biotite diatexite. $n . d .=$ not determined .

\begin{tabular}{|c|c|c|c|c|c|c|c|}
\hline Sample & 604HMM & $605 \mathrm{HMM}$ & $108 \mathrm{NKK}$ & 39MIL & 601HMM & $602 \mathrm{HMM}$ & 603HMM \\
\hline Rock code & 1 & 1 & 1 & 1 & 2 & 2 & 2 \\
\hline $\mathrm{SiO}_{2} \quad \mathrm{wt} \%$ & 64.90 & 67.70 & 65.52 & 64.18 & 65.40 & 63.50 & 62.80 \\
\hline $\mathrm{TiO}_{2}$ & 0.89 & 0.74 & 0.90 & 0.87 & 0.96 & 1.15 & 1.11 \\
\hline $\mathrm{Al}_{2} \mathrm{O}_{3}$ & 16.00 & 15.70 & 15.54 & 15.69 & 15.60 & 15.80 & 16.6 \\
\hline $\mathrm{Fe}_{2} \mathrm{O}_{3}$ tot & 6.23 & 4.82 & 6.38 & 6.53 & 5.94 & 7.07 & 7.13 \\
\hline $\mathrm{MnO}$ & 0.08 & 0.07 & 0.08 & 0.12 & 0.05 & 0.06 & 0.06 \\
\hline $\mathrm{MgO}$ & 2.22 & 1.82 & 2.19 & 2.23 & 2.10 & 2.39 & 2.51 \\
\hline $\mathrm{CaO}$ & 2.78 & 2.38 & 2.67 & 3.00 & 2.95 & 3.39 & 4.45 \\
\hline $\mathrm{Na}_{2} \mathrm{O}$ & 2.88 & 3.00 & 2.87 & 2.89 & 2.90 & 3.18 & 3.66 \\
\hline $\mathrm{K}_{2} \mathrm{O}$ & 3.42 & 3.45 & 3.30 & 3.63 & 3.52 & 2.81 & 1.16 \\
\hline $\mathrm{P}_{2} \mathrm{O}_{5}$ & 0.29 & 0.10 & 0.22 & 0.31 & 0.24 & 0.36 & 0.29 \\
\hline $\mathrm{S}$ & 0.17 & 0.09 & n.d. & 0.14 & 0.16 & 0.19 & 0.17 \\
\hline Total & 99.86 & 99.87 & 99.67 & 99.59 & 99.82 & 99.90 & 99.94 \\
\hline $\mathrm{Rb} \mathrm{ppm}$ & 138 & 129 & 125 & 104 & 94 & 78 & 32 \\
\hline $\mathrm{Ba}$ & 663 & 743 & 741 & 1358 & 930 & 710 & 200 \\
\hline $\mathrm{Sr}$ & 190 & 189 & 212 & 254 & 186 & 182 & 177 \\
\hline Th & 7 & 26 & 15 & n.d. & 10 & 5 & 2 \\
\hline $\mathrm{U}$ & 4 & 1 & 1 & n.d. & 7 & 8 & 3 \\
\hline $\mathrm{Zr}$ & 237 & 192 & 141 & 244 & 220 & 240 & 250 \\
\hline Y & 34 & 36 & 26 & n.d. & 12 & 13 & 10 \\
\hline $\mathrm{Cr}$ & 87 & 68 & 59 & 90 & 82 & 88 & 81 \\
\hline $\mathrm{Ni}$ & 30 & 20 & 39 & 29 & 30 & 20 & 20 \\
\hline V & 91 & 69 & 88 & n.d. & 116 & 142 & 127 \\
\hline $\mathrm{Zn}$ & 90 & 70 & 88 & 115 & 90 & 120 & 140 \\
\hline $\mathrm{La}$ & 40 & 100 & 50 & 40 & 60 & 70 & 50 \\
\hline $\mathrm{Ce}$ & 90 & 180 & n.d. & 87 & 100 & 90 & 100 \\
\hline $\mathrm{A} / \mathrm{CNK}$ & 1.19 & 1.21 & 1.18 & 1.11 & 1.12 & 1.09 & 1.08 \\
\hline A/NK & 1.90 & 1.81 & 1.87 & 1.81 & 1.82 & 1.91 & 2.28 \\
\hline $\mathrm{Rb} / \mathrm{Sr}$ & 0.73 & 0.68 & 0.59 & 0.41 & 0.51 & 0.43 & 0.18 \\
\hline $\mathrm{Ba} / \mathrm{Rb}$ & 4.80 & 5.77 & 5.93 & 13.06 & 9.89 & 9.10 & 6.25 \\
\hline $\mathrm{K} / \mathrm{Rb}$ & 206 & 222 & 219 & 290 & 311 & 299 & 301 \\
\hline
\end{tabular}

$M g$-numbers $[100$ x cation $\mathrm{Mg} /(\mathrm{Mg}+\mathrm{Fe})]$ vary between 40.5 and 43.8 . The biotite diatexites studied are characterized by relatively high $\mathrm{TiO}_{2}(0.7-$ $0.9 \mathrm{wt} \%), \mathrm{MgO}(1.8-2.2 \mathrm{wt} \%)$ and $\mathrm{CaO}(2.4-3.0$ $\mathrm{wt} \%$ ) as compared to many S-type granitoids (e.g. Chappell \& White 1992).

The Kauhava orthopyroxene-biotite diatexites have high $\mathrm{TiO}_{2}(1.0-1.2 \mathrm{wt} \%)$ and sum of $\left(\mathrm{Fe}_{2} \mathrm{O}_{3}\right.$ tot $\left.+\mathrm{MgO}\right)($ total 8.0-9.6 wt $\%)$ at a given $\mathrm{SiO}_{2}$ - in terms of their granitic outlook (Table 1). For example, the concentration of $\mathrm{TiO}_{2}$ and $\mathrm{MgO}$ is high but $\mathrm{Zr}$ is low ( $240 \mathrm{ppm})$ compared to the CFGC post-kinematic mangerites of similar ap- pearance (Figs. 5b-5d). Mg-number ranges from 40.1 to 41.1 . The relatively $\mathrm{Al}_{2} \mathrm{O}_{3}$-poor $(\sim 16 \mathrm{wt} \%)$ composition of the diatexites favours the formation of orthopyroxene rather than cordierite or garnet+cordierite.

Because the mica gneisses and mica schists situated eastwards of Kauhava contain greywacke interbeds, chemical analyses made from them scatter widely on the diagrams (Fig. 6). Thus the chemical composition of this metasedimentary rock suite (likely protolith for the diatexites studied) does not refer to a pelite, but it rather refers to a mixture of pelite and greywacke composi- 
a )

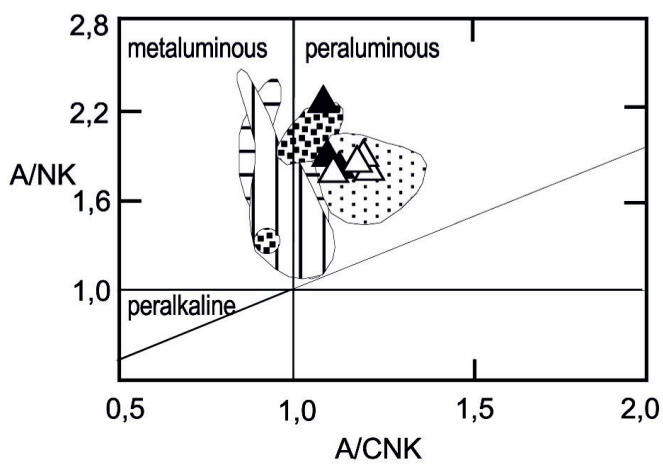

C )

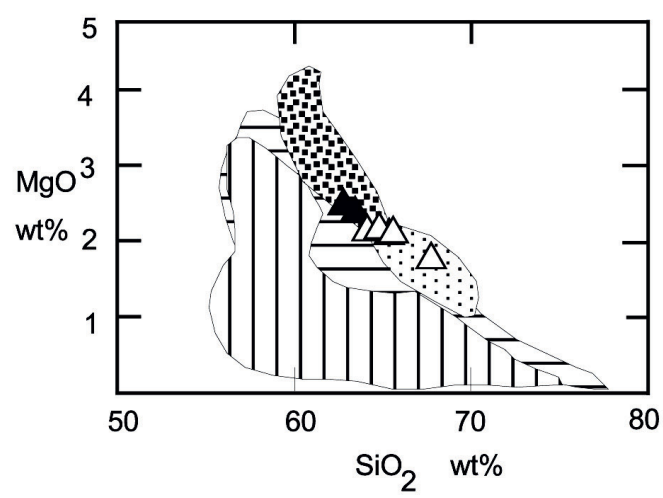

b )

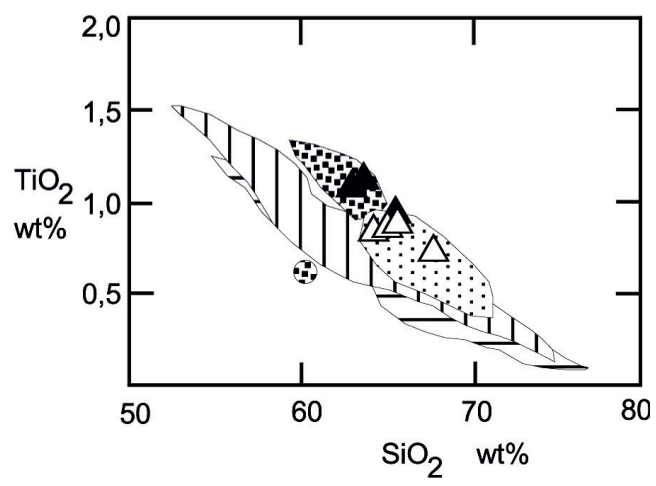

d )

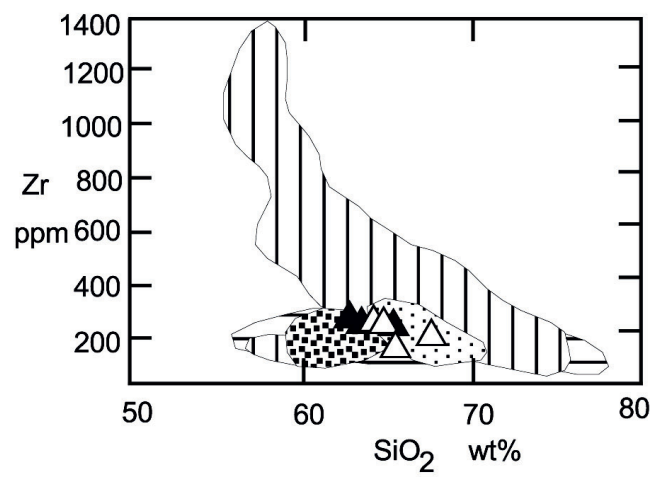

Fig. 5. Classification and discrimination diagrams for the Kauhava diatexites. a) Molecular A/NK vs. A/CNK diagram after Maniar and Piccoli (1989), b) $\mathrm{TiO}_{2}$ vs. $\mathrm{SiO}_{2}$ diagram, c) $\mathrm{MgO}$ vs. $\mathrm{SiO}_{2}$ diagram, d) $\mathrm{Zr}$ vs. $\mathrm{SiO}_{2}$ diagram. Symbols: $\triangle$ = biotite diatexite, $\boldsymbol{\Delta}=$ orthopyroxene-biotite diatexite. Lightly spotted field = biotite diatexites in the southern part of the VMC (after Mäkitie et al. 1999), heavily spotted field = orthopyroxene-biotite diatexites in the southern part of the VMC (after Mäkitie 2000), horizontally striped field = synkinematic granitoids of the CFGC (after Nironen et al. 2000), vertically striped field = post-kinematic orthopyroxene-bearing granitoids of the CFGC (after Nironen et al. 2000 and Elliott 2001).

tions. The occurrence of calcareous concretions (common in greywacke interbeds of the nearby metapelites) in the VMC indicates that the source should also contain greywacke.

\section{Mineral chemistry}

A few coexisting garnet-biotite pairs, garnet-orthopyroxene-plagioclase assemblages and isolated grains were analysed from the orthopyroxenebiotite diatexites (Table 2). The analysed points are from the cores of minerals if not otherwise mentioned.

Garnet is almandine rich having a $\mathrm{MgO}$ content of 4.2-5.5 wt\%, with $\mathrm{X}_{\mathrm{Mg}}$ [mole fraction of magnesium, $\mathrm{MgO} /(\mathrm{MgO}+\mathrm{FeO})]$ between 0.18-0.23. $\mathrm{MnO}$ content in the mineral is relatively high, over $1 \mathrm{wt} \%$. Orthopyroxene is rather rich in aluminium $\left(\mathrm{Al}_{2} \mathrm{O}_{3}\right.$ up to $\left.3 \mathrm{wt} \%\right)$ - a common feature for highgrade metamorphic orthopyroxenes (Deer et al. 1965). Biotite has a chemical composition often reported from high-grade metamorphic terrains: the 
Fig. 6. Plot of $\mathrm{MgO}$ vs. $\mathrm{K}_{2} \mathrm{O}$ for the Kauhava diatexites, showing the compositional field (grey area) of the nearby mica gneisses and mica schists (Niilo Kärkkäinen, unpublished data). The vectors for biotite, garnet, orthopyroxene, plagioclase and quartz are also shown. The approximate location of melt compositions from melting experiments of pelitic rocks is shown as MELT (after Patiño Douse \& Harris 1998, and references therein). Symbols as in Figure 5.

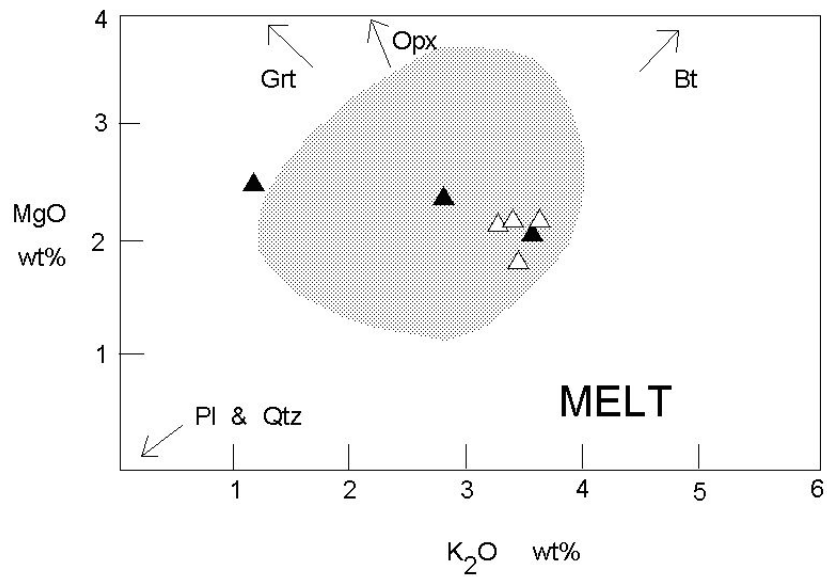

In addition to garnet, some biotite in the diatexites obviously occurred as residual phases as the solubility of $\mathrm{Fe}$ and $\mathrm{Mg}$ in granitic melts is generally low (Johannes \& Holtz 1996); for example, all iron and magnesium that occur in a biotite-rich $(\sim 20$ vol\%) rock cannot dissolve in $\mathrm{H}_{2} \mathrm{O}$-saturated or undersaturated haplogranitic melts at pressures of $5 \mathrm{kbar}$ and temperatures of $850{ }^{\circ} \mathrm{C}$. Orthopyroxene in the diatexites probably crystallized by reactions (1), (2) and (3) with melt (for references to the reactions, see Percival 1991 and Vielzeuf \& Montel 1994) and occurred in a solid state.

$\mathrm{Bt}+\mathrm{Qtz} \pm \mathrm{Kfs} \pm \mathrm{Pl} \pm \mathrm{V}=\mathrm{Opx}+\mathrm{L}$
$\mathrm{Bt}+\mathrm{Qtz}+\mathrm{Pl}=\mathrm{Opx}+\mathrm{L} \pm \mathrm{Grt} \pm \mathrm{Kfs}$
$\mathrm{Bt}+\mathrm{Qtz}=\mathrm{Opx}+\mathrm{Grt}+\mathrm{Kfs}+\mathrm{Ilm}+\mathrm{L}$

Because calcareous concretions occur in the VMC diatexites and nearby mica gneisses, fluids may have included $\mathrm{P}_{\mathrm{CO} 2}$ (that changed the $\mathrm{a}_{\mathrm{H} 2 \mathrm{O}}$ ) during melting. Unfortunately, the $\mathrm{C}$ content of the diatexites is not known. Low $\mathrm{a}_{\mathrm{H} 2 \mathrm{O}}$ is essential for the crystallization of orthopyroxene (e.g. Spear 1993).

In the $\mathrm{MgO}$ versus $\mathrm{K}_{2} \mathrm{O}$ diagram (Fig. 6), the diatexites plot within the field of their likely protolith, the metasedimentary rocks eastwards of Kauhava. In terms of the arrows representing vectors for the main residuum phases (orthopyroxene, garnet, biotite, plagioclase and quartz), the orthopyroxene-biotite diatexites contain relatively more residual minerals of garnet and orthopyroxene than the biotite diatexites which lie closer to the experimental melt composition of pelitic rocks (see place in the metatexites at Kauhava, because garnet and cordierite are common in their leucosomes. 
Table 2. Electron microprobe analyses of minerals from the orthopyroxene-biotite diatexites, Kauhava area. Oxygens: Grt 12, Bt 11, Opx 6, Pl 8.

\begin{tabular}{|c|c|c|c|c|c|c|c|c|c|c|c|c|}
\hline \multirow{2}{*}{$\begin{array}{l}\text { Sample } \\
\text { Mineral }\end{array}$} & \multicolumn{2}{|c|}{$602 \mathrm{HMM}$} & \multicolumn{2}{|c|}{ 603HMM } & \multicolumn{3}{|c|}{ 603HMM } & \multirow{2}{*}{$\frac{601 \mathrm{HMM}}{\mathrm{Bt}}$} & \multicolumn{2}{|c|}{$601 \mathrm{HMM}$ 602HMM } & \multirow{2}{*}{$\begin{array}{c}\frac{602 \mathrm{HMM}}{\mathrm{Pl}} \\
\text { (core) }\end{array}$} & \multirow{2}{*}{$\begin{array}{c}\text { 602HMM } \\
\begin{array}{c}\mathrm{Pl} \\
(\mathrm{rim})\end{array}\end{array}$} \\
\hline & Grt & $\overline{\mathrm{Bt}}$ & Grt & $\mathrm{Bt}$ & Opx & Grt & $\mathrm{Pl}$ & & Opx & Opx & & \\
\hline $\mathrm{SiO}_{2} \mathrm{wt} \%$ & 36.97 & 35.03 & 37.34 & 35.50 & 48.75 & 37.22 & 58.75 & 35.00 & 48.16 & 48.41 & 56.61 & 59.20 \\
\hline $\mathrm{TiO}_{2}$ & 0.05 & 5.22 & 0.00 & 4.28 & 0.13 & 0.00 & 0.00 & 4.37 & 0.08 & 0.17 & 0.03 & 0.00 \\
\hline $\mathrm{Al}_{2} \mathrm{O}_{3}$ & 21.29 & 15.29 & 21.24 & 14.79 & 2.70 & 21.27 & 25.61 & 15.27 & 2.40 & 2.99 & 27.10 & 25.21 \\
\hline FeOtot & 32.72 & 20.74 & 33.64 & 17.26 & 31.04 & 33.88 & 0.06 & 20.16 & 32.87 & 32.13 & 0.03 & 0.01 \\
\hline $\mathrm{MnO}$ & 1.11 & 0.04 & 0.96 & 0.19 & 0.38 & 1.12 & 0.07 & 0.06 & 0.52 & 0.39 & 0.07 & 0.00 \\
\hline $\mathrm{MgO}$ & 5.35 & 9.50 & 4.19 & 1.76 & 15.10 & 4.25 & 0.00 & 10.34 & 14.05 & 14.18 & 0.00 & 0.00 \\
\hline $\mathrm{CaO}$ & 1.54 & 0.00 & 2.36 & 0.03 & 0.15 & 2.28 & 7.36 & 0.01 & 0.23 & 0.20 & 8.84 & 6.79 \\
\hline $\mathrm{Na}_{2} \mathrm{O}$ & 0.00 & 0.06 & 0.01 & 0.26 & 0.00 & 0.01 & 7.37 & 0.03 & 0.00 & 0.00 & 6.37 & 7.39 \\
\hline $\mathrm{K}_{2} \mathrm{O}$ & 0.02 & 9.38 & 0.00 & 9.34 & 0.03 & 0.03 & 0.24 & 9.31 & 0.04 & 0.03 & 0.16 & 0.24 \\
\hline $\mathrm{F}$ & 0.26 & 0.42 & 0.16 & 0.88 & 0.20 & 0.26 & 0.00 & 0.72 & 0.23 & 0.31 & 0.09 & 0.08 \\
\hline Total & 99.31 & 95.70 & 99.90 & 94.33 & 98.48 & 100.32 & 99.46 & 95.27 & 98.58 & 98.81 & 99.30 & 98.92 \\
\hline$X_{\mathrm{Mg}}$ & 0.23 & 0.45 & 0.18 & 0.55 & 0.46 & 0.18 & 0.00 & 0.48 & 0.43 & 0.44 & 0.00 & 0.00 \\
\hline $\mathrm{Si}$ & 2.966 & 2.703 & 2.988 & 2.750 & 1.931 & 2.975 & 2.639 & 2.714 & 1.929 & 1.924 & 2.559 & 2.667 \\
\hline $\mathrm{Al}$ & 2.013 & 1.391 & 2.003 & 1.350 & 0.126 & 2.004 & 1.356 & 1.395 & 0.113 & 0.140 & 1.444 & 1.339 \\
\hline $\mathrm{Ti}$ & 0.003 & 0.303 & 0.000 & 0.249 & 0.004 & 0.000 & 0.000 & 0.255 & 0.002 & 0.005 & 0.001 & 0.000 \\
\hline $\mathrm{Mg}$ & 0.640 & 1.093 & 0.500 & 1.358 & 0.892 & 0.506 & 0.000 & 1.195 & 0.839 & 0.840 & 0.000 & 0.000 \\
\hline $\mathrm{Fe}$ & 95 & 1.339 & 2.251 & 1.118 & 1.028 & 2.265 & 0.002 & 1.307 & 1.101 & 1.068 & 0.001 & 0.000 \\
\hline Mn & 0.075 & 0.003 & 0.065 & 0.012 & 0.013 & 0.076 & 0.003 & 0.004 & 0.018 & 0.013 & 0.003 & 0.000 \\
\hline $\mathrm{Ca}$ & 0.132 & 0.000 & 0.202 & 0.002 & 0.006 & 0.195 & 0.354 & 0.001 & 0.010 & 0.009 & 0.428 & 0.328 \\
\hline $\mathrm{Na}$ & 0.000 & 0.009 & 0.002 & 0.039 & 0.000 & 0.002 & 0.642 & 0.005 & 0.000 & 0.000 & 0.558 & 0.646 \\
\hline K & 0.002 & 0.923 & 0.000 & 0.923 & 0.002 & 0.003 & 0.014 & 0.921 & 0.002 & 0.002 & 0.009 & 0.014 \\
\hline
\end{tabular}

Fig. 6). As the biotite diatexites lie close to the experimental melt composition, they may represent melt-rich diatexite, however, without significant melt-residuum separation. The relatively high concentrations of $\mathrm{Ti}, \mathrm{Fe}, \mathrm{Mg}$ and $\mathrm{Ca}$ in the studied diatexites are a reflection of the source as these elements occur in relatively high concentrations in the nearby metapelites (see Kärkkäinen 1993).

The differences in the orthopyroxene-biotite diatexites and biotite diatexites may have two interpretations: (1) the former rocks represent places where the biotite dehydration reactions have advanced the most and part of the melt was then removed leaving behind residuum, and the latter rocks represent places where melt-enrichment occurred (with some residual biotite), or (2) the protolith of the orthopyroxene-biotite diatexites is less pelitic compared to that of the biotite diatexites (as indicated by high $\mathrm{CaO}$ and $\mathrm{Na}_{2} \mathrm{O}$ in the former).

The studied VMC biotite diatexites do not ap- pear to be as residual as the diatexites from Maine, USA, described by Solar and Brown (2001). They appear to have more similarity with the mesocratic diatexites from St. Malo, France (see Milord et al. 2001), with the exception of Ca. The Kauhava orthopyroxene-biotite diatexites share chemical similarities with slightly ascended orthopyroxene diatexites in the Ashuanipi Complex, Canada, reported by Percival (1991) but the Kauhava diatexites have lower orthopyroxene/biotite mode. Geochemically, the biotite diatexites and orthopyroxene-biotite diatexites in the Kauhava area are similar to those reported from the southern part of the VMC (see Mäkitie et al. 1999, Mäkitie 2000) (Fig. 5).

The relatively high $\mathrm{A} / \mathrm{CNK}$, in particular, in the Kauhava biotite diatexites and orthopyroxene-biotite diatexites indicate a source different from that (rocks of intermediate composition with magmatic addition from the mantle) reported for the CFGC synkinematic granitoids and post-kinematic mangerites by Nironen et al. (2000) (Fig. 5a). Moreo- 
ver, the mineral assemblage Opx-Grt-Bt without amphiboles in the Kauhava diatexites is dissimilar to the CFGC mangerites. Orthopyroxene in the studied diatexites differs from those in the CFGC rocks (see Elliott et al. 1998): the Al content and $\mathrm{Mg} / \mathrm{Fe}$ in the mineral are higher in the Kauhava diatexites. Due to the A/CNK $(\sim 1.1)$, the studied orthopyroxene-biotite diatexites also differ from some foliated hornblende free orthopyroxene-biotite tonalites of southern Finland (see Mäkitie 1993).

The Kauhava area belongs to a northern highgrade metamorphic terrane separate from another high-grade terrane situated c. $90 \mathrm{~km}$ south (Mäkitie 2000). In the northern one, orthopyroxene-bearing rocks indicating granulite-grade metamorphism are found only near the boundary of the VMC. This, with the fact that granitic aspect in the diatexites generally increases toward the centre of the $\mathrm{VMC}$, may indicate that important variables $\left(\mathrm{P}_{\mathrm{H} 2 \mathrm{O}}\right.$, geothermal gradient, $\mathrm{T}$, melt fraction) differed from the centre to the margins of the VMC.

The observations presented here support the idea that the VMC represents the most voluminous in situ crustal melting in the Finnish Svecofennides. The orthopyroxene-biotite diatexites seem to form their own class of rocks with granitoid appearance in Finland. Further studies in the VMC should include REE geochemistry and isotope geology, for example $\mathrm{Sm} / \mathrm{Nd}$.

\section{ACKNOWLEDGEMENTS. I thank Michael Brown and E.W. Sawyer for their comments on the manu- script. Kind thanks also go to Lassi Pakkanen for making the microprobe analyses and to my col- leagues Niilo Kärkkäinen and Matti I. Lehtonen for providing chemical data. The Geological Sur- vey of Finland is thanked for the opportunity to make this article. The English of the manuscript was checked by Juhani Ojala.}

\section{REFERENCES}

Alviola, R., Mänttäri, I., Mäkitie, H. \& Vaasjoki, M. 2001. Svecofennian rare-element granitic pegmatites of the Ostrobothnia region, western Finland; their metamorphic environment and time of intrusion. In: Mäkitie, H. (ed.)
Svecofennian granitic pegmatites (1.86-1.79 Ga) and quartz monzonite $(1.87 \mathrm{Ga})$, and their metamorphic environment in the Seinäjoki region, western Finland. Geological Survey of Finland, Special Paper 30, 9-29.

Chappell, B.W. \& White, A.J.R. 1992. I- and S-type granites in the Lachlan Fold Belt. Transactions of the Royal Society of Edinburgh: Earth Sciences, 83, 1-26.

Clemens, J.D. \& Droop, G.T.R. 1998. Fluids, P-T paths and the fates of anatectic melts in the earth's crust. Lithos 44, 21-36.

Collins, W.J., Flood, R.H., Vernon, R.H. \& Shaw, S.E. 1989. The Wuluma granite, Arunta Block, central Australia: an example of in situ, near-isochemical granite formation in a granulite-facies terrane. Lithos 23, 63-83.

Deer, W.A., Howie, R.A. \& Zussmann, J. 1965. An Introduction to the Rock-forming Minerals. London: Longmans. $528 \mathrm{p}$.

Elliott, B.A. 2001. The petrogenesis of the 1.88-1.87 Ga post-kinematic granitoids of the Central Finland Granitoid Complex. Academic disseration. University of Helsinki. Yliopistopaino. 36 pages with 5 original papers.

Elliott, B.A., Rämö, O.T. \& Nironen, M. 1998. Mineral chemistry constraints on the evolution of the 1.88-1.87 Ga post-kinematic granite plutons in the Central Finland Granitoid Complex. Lithos 45, 109-129.

Johannes, W. \& Holtz, F. 1996. Petrogenesis and Experimental Petrology of Granitic Rocks. Berlin: SpringerVerlag. 335 p.

Kärkkäinen, N. 1993. Etelä-Pohjanmaan liuskejakson malmipotentiaali kallioperän geokemian perusteella. Lic. Phil. thesis. Department of Geology, University of Oulu. 232 p. (in Finnish)

Koistinen, T.J., Korsman, K. \& Virransalo, P. 2000. Paleoproterozoic trondhjemite migmatites in southern Finland. In: Pesonen, L.J., Korja, A. \& Hjelt, S.-E. (eds.) Lithosphere 2000: a symposium on the structure, composition and evolution of the lithosphere in Finland, Espoo, Otaniemi, October 4-5, 2000. Programme and extended abstracts. Institute of Seismology, University of Helsinki. Report S-41, 97-100.

Korsman, K., Koistinen, T., Kohonen, J., Wennerström, M., Ekdahl, E., Honkamo, M., Idman, H. \& Pekkala, Y. (eds.) 1997. Suomen kallioperäkartta - Berggrundskarta över Finland - Bedrock map of Finland. 1 : 1000000. Geological Survey of Finland.

Lahermo, P., Ilmasti, M., Juntunen, R. \& Taka, M. 1990. The Geochemical Atlas of Finland, Part 1: The hydrogeochemical mapping of Finnish groundwater. Geological Survey of Finland. Espoo. 66 p.

Laitakari, A. 1942. Kivilajikartan selitys. Suomen geologinen yleiskartta. Lehti B3, Vaasa. Geological Survey of Finland. (in Finnish)

Lundqvist, T. \& Autio, S. (eds.) 2000. Description to the bedrock map of Central Fennoscandia (Mid-Norden). Geological Survey of Finland, Special Paper 28. 176 p.

Mäkitie, H. 1993. P-T determinations of tonalite from Östersundom - lower granulite facies mineral assemblages in Sipoo, southern Finland. In: Autio, S. (ed.) Geological Survey of Finland, Current Research 1991- 
1992. Geological Survey of Finland, Special Paper 18, 19-24.

Mäkitie, H. 2000. Granitoids (1.89-1.87 Ga), diatexites (1.89-1.88 Ga) and granitic pegmatites (1.80-1.79 Ga), and structural-metamorphic evolution in the Seinäjoki region, western Finland. Academic dissertation. Geological Survey of Finland, Espoo. 35 pages with 5 original papers.

Mäkitie, H., Kärkkäinen, N., Lahti, S.I. \& Lehtonen, M.I. 1999. Chemical and modal composition of granitoids in three different geological units, South-Pohjanmaa, western Finland. In: Autio, S. (ed.) Geological Survey of Finland, Current Research 1997-1998. Geological Survey of Finland, Special Paper 27, 7-19.

Maniar, P.D. \& Piccoli, P.M. 1989. Tectonic discrimination of granitoids. Geological Society of America, Bulletin 101, 635-643.

Mehnert, K.R. 1968. Migmatites and the Origin of Granitic Rocks. Developments in Petrology 1. Amsterdam: Elsevier. 405 p.

Milord, I., Sawyer, E.W. \& Brown, M. 2001. Formation of diatexite migmatite and granite magma during anatexis of semi-pelitic metasedimentary rocks: an example from St. Malo, France. Journal of Petrology 42, 487-505.

Nironen, M. 1997. The Svecofennian orogen: a geotectonic model. Precambrian Research 86, 21-44.

Nironen, M., Elliott, B.A. \& Rämö, O.T. 2000. 1.88-1.87 Ga post-kinematic intrusions of the Central Finland Granitoid Complex: a shift from C-type to A-type magmatism during lithospheric convergence. Lithos 53, 37-58.

Patiño Douce, A.E. \& Harris, N. 1998. Experimental constraints on Himalayan anatexis. Journal of Petrology 39, 689-710.

Percival, J.A. 1991. Granulite-facies metamorphism and crustal magmatism in the Ashuanipi Complex, QuebecLabrador, Canada. Journal of Petrology 32, 1261-1298.

Saksela, M. 1935. Über den geologischen Bau Süd-Ostbothniens. Bulletin de la Commission Géologique de Finlande 110. 35 p.

Sawyer, E.W. 1998. Formation and evolution of granite magmas during crustal reworking: the significance of diatexites. Journal of Petrology 39, 1147-1167.
Sawyer, E.W. 1999. Criteria for the recognition of partial melting. Physics and Chemistry of the Earth. Part A: Solid Earth and Geodesy 24, 269-279.

Solar, G.A. \& Brown, M. 2001. Petrogenesis of migmatites in Maine, USA: possible source of peraluminous leucogranite in plutons. Journal of Petrology 42, 789-823.

Spear, F.S. 1993. Metamorphic Phase Equilibria and Pressure-Temperature-Time Paths. Mineralogical Society of America. Monograph. 799 p.

Vaarma, M. \& Pipping, F. 1998. Alajärven ja Evijärven kartta-alueiden kallioperä. Summary: Pre-Quaternary rocks of the Alajärvi and Evijärvi map-sheet areas. Geological map of Finland 1 : 100 000, Explanation to the maps of Pre-Quaternary rocks, Sheets 2313 and 2314. Geological Survey of Finland. 83 p.

Vaasjoki, M. 1996. Explanation to the geochronological map of southern Finland: the development of the continental crust with special reference to the Svecofennian orogeny. Geological Survey of Finland, Report of Investigation $135.30 \mathrm{p}$.

van der Molen, I. \& Paterson, M.S. 1979. Experimental deformation of partially-melted granite. Contributions to Mineralogy and Petrology 70, 299-318.

Väyrynen, H. 1936. Über die altersverhältnisse der granite von Süd-Finnland und Pohjanmaa. Bulletin de la Commission Géologique de Finlande 115, 251-266.

Vernon, R.H. \& Collins, W.J. 1988. Igneous microstructures in migmatites. Geology 16, 1126-1129.

Vielzeuf, D. \& Montel, J.M. 1994. Partial melting of metagreywackes. Part 1. Fluid-absent experiments and phase relationships. Contributions to Mineralogy and Petrology 117, 375-393.

White, R.W., Powell, R. \& Holland, T.J.B. 2001. Calculation of partial melting equilibria in the system $\mathrm{Na}_{2} \mathrm{O}$ $\mathrm{CaO}-\mathrm{K}_{2} \mathrm{O}-\mathrm{FeO}-\mathrm{MgO}-\mathrm{Al}_{2} \mathrm{O}_{3}-\mathrm{SiO}_{2}-\mathrm{H}_{2} \mathrm{O}$ (NCKFMASH). Journal of Metamorphic Geology 19, 139-154.

Wyllie, P.J. 1983. Experimental studies on biotite- and muscovite-granites and some crustal magmatic sources. In: Atherton, M.P. \& Gribble, C.D. (eds.) Migmatites, Melting and Metamorphism. Nantwich, Cheshire: Shiva, 12-26. 